\title{
THE SOURCE DOMAIN OF JAVANESE WOMEN BODY SHAPE IN KYAI SESTRADILARAS MANUSCRIPT
}

\author{
Khoirur Rahmah \\ Faculty of Cultural Sciences \\ Gadjah Mada University \\ khoirur.rachmah@gmail.com \\ DOI: https://doi.org/10.24071/ijhs.2018.010205 \\ received 13 November 2017; revised 11 February 2018; accepted 19 February \\ 2018
}

\begin{abstract}
Kyai Séstradilaras manuscript is a manuscript about the image of beauty of Arjuna's wives, including outward beauty and inner beauty. In this research, the analysis of the metaphorical and simile source domains of the body shape of Javanese women in Kyai Sestradilaras manuscript on outward beauty is discussed. This research uses the metaphor theory initiated by Lakoff and Johnson (1980), the theory of source domain according to Haley (1980), and simile theory according to Abrams through Marsono (1996). The method used in this research is descriptive qualitative method. The implementation of this method consists of three stages, data collection methods, data analysis methods, and presentation of data analysis. The data in this research are obtained from the written source. The results of the research are the metaphorical and simile source domain of the body shape of Javanese women in Kyai Sĕstradilas manuscript. The source domains are 1) the moonlit sky to illustrate the beauty of a woman's eyes, 2) the sky to describe the beauty of a woman's face, 3) the dahlia flower to describe the beauty of a woman's face, 4) the fennel leaves to describe the beauty of a woman's face, 5) pomegranate to describe the beauty of a woman's face, 6) the moon to describe the beauty of a woman's skin, 7) golden money ray to describe the beauty of a woman's skin, 8) ivory palm to describe the beauty of a woman's breasts, and 9) cempaka flowers to illustrate the beauty of a woman's breasts.
\end{abstract}

Keywords: source domain, panyandra, metaphor and simile, Kyai Sestradilaras manumanuscript

\section{Introduction}

Tembang macapat is a traditional Javanese song or poem (Tofani, 1995, p.93). Each stanza can have a sentence line called gatra, and each gatra has a certain number of syllables (guru wilangan), and ends in the final rhyme sound called the song teacher. The sequences of Javanese songs are like the sequence of human life from birth to death.

Tembang macapat becomes a language research subject in this research because this research will see the phenomenon of language that comes with 
metaphor and simile approach. The poem of the song is taken from a manuscript entitled Kyai Sěstradilaras, Pura Pakualaman library collection number 0148 / PP / 73. The manuscript of Kyai Sĕstradilaras is written in Javanese with krama and ngoko, although some words adopt the Malay and Dutch words. The script used is Javanese script. There are 51 pages in the KSD manuscript.

The manuscript was written at the time of K.G.P.A.A. Paku Alam IV after being appointed as a duke of Pakualaman, on Tuesday Pahing, the 25th of Jumadilakhir Wawu 1793 mangsa Sad wuku Galungan lambang Klawu windu Karta, coinciding with the date of 25 November 1864 M. but there is a possibility that the script writing was completed in the period of K.G.P.A.A. Paku Alam V with the same writing title (Febriyanto, 2012, p.19).

The manuscript of Kyai Sestradilaras tells the story of the odyssey of Arjuna's love to his wives, the love story of Raden Arjuna along with the depiction of the beauty, nobleness, and beauty of his wives. The depiction of female beauty contains metaphors and similes, including the painting of faces, eyes, skin, breasts, walking, behavior, and words.

This research relies on the metaphorical and simile source domains of Javanese female body shape in Kyai Sestradilaras manuscript. In Old Javanese culture there is a description of the female body shape called panyandra. Panyandra explains that it is a substance between the two elements, the outside and inside. Outward beauty is the beauty of the face and body. Meanwhile, inner beauty is the virtue that shines out of the self. Furthermore, these two elements combine and provide a balance.

The description of Javanese female body shape inside and outside are things that can be compared. This is related to the study of metaphor. According Kridalaksana (2008, p.152) metaphor is the use of words or other expressions for other objects or concepts based on equation. Semantically, this is very interesting because in metaphor, the literal meaning and metaphorical meaning can be found. Lakoff and Johnson (1980, p.3) argue that metaphorical thinking illustrates that there is a basic tendency of the human mind to think of certain referents in a certain way.

Based on the background of problems, the problem studied in this research is the process of forming metaphor in the manuscript of Kyai Sestradiaras which builds description of Javanese women body shape. The purpose of this study is to analyze the metaphorical and simile source domain of the Javanese women body shape in Kyai Sestradilaras manuscript.

This research uses metaphor theory, source domain theory, and simile to answer the existing problems. This is because the three theories complement each other to analyze the data that will appear in the Kyai Sestradilaras manuscript.

\section{Metaphor Theory}

To view and analyze the data found in the Kyai Sestradilaras manuscript, this research uses the theory by Lakoff and Johnson (1980, pp.5-6) explaining the essence of a metaphor which is the understanding and experience described by experience or other understandings, so essentially human conceptual systems can be defined and structured metaphorically. Lakoff and Johnson's opinion is consistent with the explanation of Knowles and Moon (2005, p.93) that metaphor is a tool of creativity in a linguistic phenomenon because it explains things with other things, so that literary authors make it a tool in creating works. Therefore, 
metaphors are regarded as linguistic expressions embedded in one's conceptual system.

There are three main elements in metaphor (Ogden \& Richard, 1972, p.97), 1) Tenors i.e. concepts, objects that are described, discussed, characterized, denoted, or compared. Tenors are also called receptors. 2) Vehicle, a concept that describes, equates, symbolizes the tenor. Vehicle is also referred to a donor. A vehicle is a symbol or an allusion to itself. 3) Ground, the relation of equation between tenor and vehicle. The relation of this equation can be an objective equation such as shape, place, nature, or combination of them, emotive equations, conceptual equations, function equations, and social and cultural equations.

The conceptual metaphor is a cognitively formed systematic concept (Lakoff \& Johnson, 1980, p.3). The conceptual metaphor analyzed as a cognitive conceptualization process depends on three things: 1) source domain, 2) target domain, 3) mapping or correspondence (Cruse, 2004, p.201). In other words, the conceptual metaphor sees a connection between the two domains of the source and the target domain in the form of mapping or correspondence. The source domain relates to a world of concrete (real) and familiar experience, while the target domain is usually more abstract.

\section{Source Domain Theory}

Based on its comparative semantic field, the semantic field of the universal metaphor is divided into nine semantic fields (Haley, 1980, pp.155-159):

a. The metaphor of being is a metaphor that includes abstract things like truth and love.

b. The metaphor of cosmos is a metaphor which includes cosmic objects such as the sun and the moon.

c. The metaphor of energy is a metaphor with a semantic field of things that have power, such as wind, light, fire, with predictions that those things can move.

d. Substance metaphor is a metaphor that includes the kinds with predictions including moisture, odor, pressure, etc.

e. Earth terrestrial metaphors are metaphors that include things bound or sprawled on the surface of the earth such as rivers, seas, mountains, etc. in addition; this metaphor also includes matters relating to gravity that is a metaphor related to all things that fall due to the influence of earth's gravity.

f. The metaphor of inanimate objects is a metaphor which includes lifeless objects such as tables, books, chairs, glasses, etc. that can be broken.

g. Metaphor of life / plants (living) is a metaphor associated with all types of plants (flora), such as leaves, sago, rice, etc.

h. The metaphor of animate / animal beings is a metaphor related to creatures of organisms that can walk, run, fly and so forth such as horses, cats, birds and tigers.

i. Human metaphor is a metaphor related to creatures that can think and have reasons.

Simile

Simile is a style of language that compares something that is essentially different indirectly by using comparative words (Abrams in Marsono, 1996, p.449). Comparative words used are lir 'like', kadi 'like', kadya 'like', upama 'like'. 


\section{Method}

This research is a descriptive qualitative research. The object of this research is the manuscript of Kyai Sĕstradilaras, Pakualaman Pura Library collection. The manuscript has been transliterated, edited and translated into Indonesian by Muhammad Bagus Febriayanto in a thesis entitled "Kyai Sestradilaras of Pura Pakualaman Library Collection Temple (Edits, Translations and Text Analysis)" in 2012. The first stage in this research is data collection. The data collection in this research used observation method with note taking technique. Mahsun (2014) explains that observation method is the method of data provision by listening to the use of language. The term listening here is concerned not only with the use of spoken language but also the use of written language. The note taking technique according to Kesuma (2007) is the technique of capturing data by recording the results of data on the data card. Data source in this research is a written source derived from the manuscript of Kyai Séstradilaras, Pura Pakualaman library collection. After recording then the songs containing metaphor are searched and copied. Then the songs or tembang that contains the metaphor are sorted. The stages performed in this research are collecting data, classifying metaphors and simile of Javanese women body shape based on outward beauty category, analyzing the source domain of Javanese women body shape in Kyai Sestradilaras script based on Haley metaphor theory, and the last is getting the result of the metaphorical meaning analysis of the description of Javanese women body shape in Kyai Sestradilaras.

\section{Findings and Discussion}

There are 9 panyandra about the description of Javanese women body shape in Kyai Sestradilaras manuscript based on outward beauty. In this section the analysis of metaphorical meaning panyandra of Javanese woman body shape based on outward beauty category. The categories are: 1) eye characteristics, 2) facial characteristics, 3) skin characteristics, and 4) breast characteristics.

\section{Eye Characteristics}

Eyes are the five senses of vision that became one of the woman's attractive beauties. In the Kyai Séstradilaras manuscript there is one thing that becomes a symbol that shows the methaphor of eye characteristic. The target domain of the eye has the source domain metaphor as follows, ie bomaning ngateja sasi 'moonlit sky'.

Kinanthi song, gending Eman-eman Sari Pelog (p.11)

"Rupa netra retnaningrum/ bomaning ngateja sasi/ catur rupa tejaning dyah/ ponca rupa tejawati/ rasa rupa tejaninggar/ samurti rĕtnadiningsih//"

(1) Rupa

Appearance

\section{netra retnaningrum bomaning}

eyes beautiful

$$
\text { sky }
$$

"Beautiful eyes (is like) moonlit sky"

ngateja

sasi.

In example (1) having beautiful eye shape equated to the moonlit sky which is Retnaningsih's eyes. Retnaningsih is one of Arjuna's wives whose face is like a beautiful painting, bowed face, beautiful little eyes and sweet face look.

The metaphor in Example (1) basi ngateja sasi 'moonlit sky' is used for the beauty of a woman's eyes metaphor. The similarity between the source domain and the target domain is, first, the target domain of a woman's eyes beauty takes 
the nature of a clean sky to illustrate that the beauty of the woman's eyes is clean. Second, the target domain that takes the feature bright moon color and shines to illustrate that the beauty of the woman's eyes is bright and radiant. The metaphors in this example belong to the metaphorical source domain of cosmic materials.

\section{Face Characteristics}

Beautiful women have typical facial characteristics, In the Javanese society, there are some things that become symbols showing the metaphor of a woman's face characteristics. Face characteristics target domain have metaphor target domain as follows, a) boma 'sky', b) dungeon wungu 'purple red dahlia ', c) adas rondon 'fennel leaves', and d) five 'pomegranates'.

\section{Face characteristics as sky "Boma"}

The characteristic meaning of the face as the 'sky' boma on the metaphor in Kyai Séstradilaras manuscript is the face of a beautiful woman equated with the sky. The use of sky elements has a unique provision, so it becomes the choice of the Javanese in describing the word beauty which refers to the beauty of a woman. The characteristics of the sky is brightly colored, stretched wide, and has a smooth surface is compared with the characteristics of a woman's facial beauty that has a bright and smooth face, do not has many acnes or black spots. The song or tembang containing the metaphor is as follows.

Tembang Kinanthi, gending Eman-eman Sari Pelog (p.11)

Kanĕmnya Dyah Tejaningrum/ kasapta Dyah Tejarěsmi/ mutyadi Teja Asmara/ kan [g] nawa Tejadewati/bomanya sampurna watya/ warna rupa Tejaningsih//

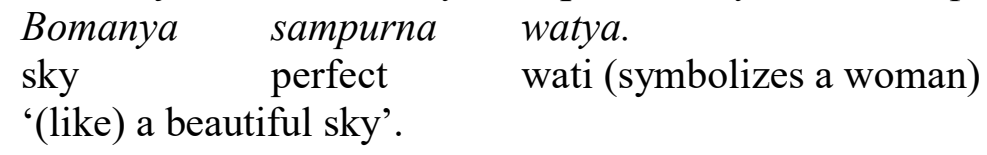

One of Arjuna's wives depicted in example (2) whose facial beauty is equated to the sky is Dyah Teja Dewati. Dyah Teja Dewati's face was so beautiful that Arjuna fell in love with her. The metaphors in this example belong to the metaphorical source domain of cosmic materials.

\section{Face Characteristic as red purple Dahlia "Daliyah Bang Wungu"}

The characteristic meaning of the face as daliyah bang wungu 'purple red dahlia flowers' on metaphors in Kyai Sěstradilaras manuscript is the face of a beautiful woman equated with the red and purple dahlia flowers. Dahlia flower is a bulbous bushy plant that is annual (perenial), eternal life, and flowering in summer until autumn. The nature of the purple red dahlia flowers can be equated to the beauty of a woman who remains beautiful in the morning and evening, his beauty will be immortal and very special in front of men. The tembang containing the metaphor is as follows.

Tembang Gawan Gending, gending Laras Driya Slendro (p.12)

(3) Sumarah sang anom/ tan giwang trap pratikĕle/ dhasar ayu ngawanggah banjar adi/ tanĕman puspadi/daliyah bang wungu//

'Resigned the princess, all her efforts are not faltering, really beautiful all beautifully planted with beautiful flowers, red pulple Dahlia'.

One of Arjuna's wives depicted in example (3) whose facial beauty is equated to purple red dahlia is Sumbadra. Sumbadra is the daughter of the late King Prabu Basudewa, a king of the Mandura, Banjarpotaman. Sumbadra is also 
the most beautiful princess in the world. The metaphors in this example belong to plant metaphor source domain.

\section{Face Characteristics as fennel leaves "Adas Rondon"}

The meaning of the face as an adas rondon 'fennel leaf' on metaphors in Kyai Serstradilaras manuscript is the face of a beautiful woman equated with fennel leaves. Fennel plants have some physical characteristics that are plants that have elongated and compounded leaves, and have many leaves. The relation of equation between facial characteristics with fennel leaves is the equation of the characteristics between facial characteristics with fennel leaves characteristics. First, the face of a beautiful woman has a firm line of face. Second, a beautiful woman's face usually has a pointed chin / taper, as well as fennel leaves that have a pointy shape on the tip and base.

Tembang Gawan Gending, gending Laras Driya Slendro (p.12)

(4) Sumarah sang anom/ tan giwang trap pratikĕle/ dhasar ayu ngawanggah banjar adi/ tanèman puspadi/ daliyah bang wungu/l

Lawan adas rondon/ jejerira dlima bangle/ dlima $<13>$ wungu tuwin dlima putih/ dlima patra wilis/ ngrëmbaka kang taru//

'Resigned the princess, all her efforts are not faltering, really beautiful all beautifully planted with beautiful flowers, red pulple Dahlia'.

'With fennel leaves parallel to the bengle pomegranate, pomegranate $<13>$ purple, white pomegranate, patra wilis pomegranate, the trees thrive'.

One of Arjuna's wives depicted in example (4) whose facial beauty is equated to an fennel leaf is Sumbadra. Sumbadra is the daughter of the late King Prabu Basudewa a king of the Mandura, Banjarpotaman. Sumbadra is also the most beautiful princess in the world. Sumbadra is very caring for her beauty, so she is told as an unequaled beautiful woman. The metaphors in this example belong to the plant metaphor source domain.

\section{Face Characteristics as pomegranate "Dlima"}

The characteristic meaning of the face as the 'pomegranate' in the metaphor of the Kyai Séstradilaras manuscript is the face of a beautiful woman equated with pomegranates. Pomegranates' physical characteristics are smooth skin surface, red color, and round fruit shape. The tembang containing the metaphor is as follows.

Tembang Gawan Gending, gending Laras Driya Slendro (page: 12)

(5) Sumarah sang anom/ tan giwang trap pratikĕle/ dhasar ayu ngawanggah banjar adi/ taněman puspadi/ daliyah bang wungu//

Lawan adas rondon/ jejerira dlima bangle/ dlima $<13>$ wungu tuwin dlima putih/dlima patra wilis/ ngrěmbaka kang taru//

'Resigned the princess, all her efforts are not faltering, really beautiful all beautifully planted with beautiful flowers, red pulple Dahlia'.

'With fennel leaves parallel to the bengle pomegranate, pomegranate $<13>$ purple, white pomegranate, patra wilis pomegranate, the trees thrive'.

One of Arjuna's wives depicted in example (5) whose facial beauty is equated to pomegranates is Sumbadra. The relation of the equation between the face beauty with the pomegranate is the equation of physical characteristics between the pomegranate with the face beauty. First, the pomegranate has a smooth skin surface depicting that the woman's facial skin is smooth. Second, the 
pomegranate has a faint red color depicting that the woman's face was a blush of red blush on the cheeks and lips. Third, the pomegranate has a round shape of fruit which means to describe the shape of a round female face. The metaphors in this example belong to the plant metaphor source domain.

\section{Skin characteristics}

The woman's skin is one of the most treatable parts of the body and the center of attention. In Javanese society, there are some things that symbolize the metaphor of women's skin characteristics. The target domain of skin characteristics has a simile of source domain as follows, ie a) sitěngsit 'moon', and b) dinar sorote 'golden money rays'.

\section{Skin Characteristics as Moon "Sitěngsit"}

The characteristic meaning of skin as sitěngsit 'moon' in the simile in the script Kyai Séstradilaras is the skin of a beautiful woman equated with the moon. The use of solar system elements in the form of the moon has a unique provision, so that the Javanese chose it in describing the word beauty that refers to the beauty of a woman's skin. The moon has a very bright light and yellow, it is the same as the beautiful woman's skin has a bright color and yellowish white. Simile in this example belongs to the simile source domain of cosmic objects. The song 'tembang' containing the simile is as follows.

Tembang Kinanthi, gending Eman-eman Sari Pelog (p.11)

Kadwinya musthikaningrum/Srikandhi rětnaning estri/ tan lĕnggana ing sakarsa/ ngimpuni para absari/ mung putri Cĕmpala arja/ crĕma maya lir sitěngsit//

(6) Crěma maya lir sitěngsit.

skin bright like moon.

'Her skin glowed like a moonlight'.

One of Arjuna's wives depicted in example (6) whose skin beauty is equated with the moon is Srikandhi. Srikandhi is a princess from Cempalaarja Country. Srikandhi is portrayed as a very beautiful woman. Her movements are all worthy and supple. Srikandhi's beauty is also depicted as yellow like a sharpened gold, a clear / radiant face like the sky, fierce but sweet eyes, lanky, her teeth are glowing. Beside of having a beautiful face, Srikandhi is also told as a daughter of an incredible soldier. She has a good archery skill and good combat.

\section{Skin characteristics as golden money ray "dinar sorote"}

The characteristic meaning of the lskin as a 'golden money ray' dinar sorote in a simile in the Kyai Sěstradilaras script is the skin of a beautiful woman equated with golden rays of gold. Gold has a shiny, bright, and yellow. The song containing the simile:

Tembang Gawan Gendhing, gending Laras Driya Slendro (p.12)

Sumbadra sang kaot/ crěma lir dinar sorote/ panukmanira sang Sinta Dewi/ rĕtnaning widadari/ bĕg budyarja ningrum//

$$
\begin{aligned}
& \text { Crěma lir dinar sorote. } \\
& \text { kulit seperti uang emas sinarnya. } \\
& \text { 'Her skin shone like golden rays of money'. }
\end{aligned}
$$

One of Arjuna's wives depicted in example (7) whose skin beauty is likened to the golden money rays is Sumbadra. The relation of the equation between Sumbadra's skin beauty with golden rays of gold is the equation of the 
nature between the beauty of sumbadra skin with golden rays of money. Beautiful women's skin has bright, yellow, and sparkling colors. Simile in this example belongs to the simile source domain of inanimate objects.

\section{Breasts Characteristics}

One part of the body that describes the beauty of a woman's body is the perfect shape of breasts, in Kyai Sěstradilaras script there are some things that symbolize the metaphor of breast characteristics. The target domain of breast characteristics has simile source domains as follows, ie a). cĕngkir gadhing 'ivory coconut', and b). cёpaka 'cempaka flower'.

\section{Breasts characteristics as ivory palm "Cĕngkir Gadhing"}

The characteristic meaning of breasts as a cengkir gadhing 'ivory palm'. Cengkir gadhing in simile in the Kyai Sěstradilaras script is a perfect breast shape likened to ivory palm. cengkir gadhing consists of the word cengkir meaning 'young coconut' (Poerwadarminta, 1939, p.635) and the word 'gadhing' type of coconut tree with generally small fruit '(Poerwadarminta, 1939, p.127). Ivory palm has a medium size, not the same as the coconut in general that has a large size. In the text Kyai Séstradilaras, the equation relation between the characteristics of breasts with ivory palm is the the equation between the characteristics of breasts form with ivory palm, which is the description of medium-sized and toned breasts. The song 'Tembang' containing the simile:

Tembang Megatruh, geding Drawina Pelog (p.14)

(8) Pan pinaring cĕpěngan pundhak para rum/ suswarja lir cĕngkir gadhing/ Engge/ Bok Lara gěndhis ingutus/ udhĕtira gadhung mlathi/ babo mondakaki sěkarnya mrok//

'the women have been given a handle (flowers) pudhak. Their breasts are like ivory palm. Engge. Mbok Lara Gendhis is sent, her belt is like (garlands) gadung (and) jasmines (which are) about to bloom'.

In example (8) whose perfect breast shape is equated with ivory coconut is Srikandhi's breasts. Srikandhi is a very beautiful woman and has beautiful breasts with medium size and still tight. Simile in this example belongs to the simile source domain of plant.

\section{Breasts characterisics as cempaka flower "Cĕpaka"}

The characteristic meaning of breast as cepaka 'cempaka flower' in simile in Kyai Sĕstradilaras script is the perfect breast shape equated with cempaka flower. Cempaka flower is a yellow and white flower, its flower buds are shaped like a half ball. The relation of the similarity between breast characteristics with cempaka flowers is the similarity between the breast shape with cempaka flowers. Breast of a young woman is still tight and like a half ball, as well as flower buds that look like a half ball. The song 'tembang' containing the simile is as follows. Tembang Gawan Gendhing, gending Mimi Pelog (p.40)

(9) Tindak mring langon paladi/ kang dherek para bedhaya/ asinjang grompol prasami/ udhĕt ingga tinĕpi/ mĕksih timur dadya pinjung/ suswarja lir ceеpaka//

'(They) go to langon paladi followed by the (dancers) bedaya (motif) gerempol. (the dancers are wearing) udhet to form into a fist. (they are dancers who) are still young (their) breasts is like (flowers) cempaka'.

In data (9) whose breast characteristics are equated with cempaka flowers is the breasts of bedhaya dancers. Bedhaya dancers are young, very beautiful and 
have a beautiful body shape. One of the beautiful body parts is the breasts, the bedhaya dancers' breasts are in medium size and it is still tight. Simile in this example belongs to the simile source domain of plant.

\section{Conclusion}

Based on the nine panyandra that have been analyzed, about the source domains of metaphorical and simile of the body shape of Javanese women in Kyai Sestradilaras manuscript. The nine panyandra of Javanese women body shape in Kyai Sestradilaras manuscript is divided into four categories, 1) eye characteristics, 2) facial characteristics, 3) skin characteristics, and 4) breast characteristics. The source domains of the nine panyandra of Javanese women body shape are abstract and concrete, and they are often encountered in the daily life of Javanese society. The source domains are 1) the moonlit sky to illustrate the beauty of a woman's eyes, 2) the sky to describe the beauty of a woman's face, 3 ) the dahlia flower to describe the beauty of a woman's face, 4) the fennel leaves to describe the beauty of a woman's face, 5) the pomegranate fruit to describe the beauty of a woman's face, 6) the moon to describe the beauty of a woman's skin, 7) the golden money ray to depict the beauty of a woman's skin, 8) ivory palm to depict the beauty of a woman's breasts, and 9) cempaka flowers to illustrate the beauty of a woman's breasts. From those descriptions, the nine panyandra of Javanese women body shape in Kyai Sestradilaras manuscript refers to the outward beauty of women. However, the real beauty of women is not only the outward beauty, but also the inner beauty.

\section{References}

Cruse, A. (2004). Meaning in language: An introduction to semantics and pragmatics $\left(2^{\text {nd }}\right.$ ed.). Oxford: Oxford University Press.

Febriyanto, M.B. (2012). Kyai sěstradilaras: Suntingan, terjemahan, dan analisis teks (Skripsi, Fakultas Ilmu Budaya Universitas Gadjah Mada, 2012).

Halley, M.C. et.al. (1980). Linguistisc prespective on literature. London: Rougtlededge \& Kaegan Paul.

Keraf, G. (2010). Diksi dan gaya bahasa. Jakarta: PT Gramedia.

Kesuma, T.M.J. (2007). Pengantar metode penelitian bahasa. Yogyakarta: Carasvatibooks.

Knowless, Muray., \& Moon, R. (2006). Introducing metaphor. New York: Rouledge Taylor.

Kovesces, Z. (2000). Metaphor and emotion. Cambridge: Cambridge University Press.

Kovesces, Z. (2005). Methapor in culture. United Kingdom: Cambridge University Press.

Kovesces, Z. (2010). Metaphora a practical introduction (2 ${ }^{\text {nd }}$ ed.). New York: Oxford University Press.

Kridalaksana, H. (2008). Kamus linguistik. Jakarta: PT. Gramedia Pustaka Utama. Knowles, M., \& Moon, R. (2005). Introducing methapor. New York: Routledge.

Lakoff., \& Johnson. (1980). Metaphor we life by. Chicago: The University of Chicago Press.

Lyons, J. (1996). Linguistics semantics: An introduction. Cambridge: Cambridge University Press. 
Mahsun. (2014). Metode penelitian bahasa: Tahapan strategi, metode, dan tekniknya. Jakarta: Raja Grafindo Persada

Ogden, C. K., \& Richard, L.A. (1972). The mening of meaning. London: Rouledge and Kegan Paul LTD

Parera, J.D. (2004). Teori semantik. Jakarta: Penerbit Erlangga.

Poerwadarminta. (1939). Baoesastra Djawa. Batavia: J.B. Wolters Uitgevers Maatschappij N.V.

Prawiroatmodjo. (1981). Bausastra Jawa-Indonesia. Jakarta: Gunung Agung.

Subroto, E. (2011). Pengantar studi semantik dan pragmatik. Surakarta: Cakrawala Media.

Tarigan, H.G. (1985). Pembelajaran gaya bahasa. Bandung: Angkasa.

Tasaro. (2012). Kinanthi terlahir kembali. Yogyakarta: PT. Bentang Pustaka.

Tofani, M.A. (1995). Sari-sari basa jawi pepak. Tuban: Yayasan Amanah.

Wahab, A. (1995). Teori semantik. Surabaya: Airlangga University Press.

Wahab, A. (1990). Metafora sebagai alat pelacak sistem ekologi. Yogyakarta: Kanisius.

Wahab, A. (1991). Isu linguistik pengajaran bahasa dan sastra. Surabaya: Airlangga University Press. 